\title{
Pesticides effect on soil microbial ecology and enzyme activity- An overview
}

\author{
Sanjay Arora and Divya Sahni* \\ ICAR-Central Soil Salinity Research Institute, Regional Research Station, Lucknow- 226002 (U.P.), INDIA \\ *Corresponding author. E-mail: divya.sahni565@gmail.com
}

Received: August 6, 2015; Revised received: January 27, 2016; Accepted: May 29, 2016

\begin{abstract}
In modern agriculture, chemical pesticides are frequently used in agricultural fields to increase crop production. Besides combating insect pests, these insecticides also affect the activity and population of beneficial soil microbial communities. Chemical pesticides upset the activities of soil microbes and thus may affect the nutritional quality of soils. This results in serious ecological consequences. Soil microbes had different response to different pesticides. Soil microbial biomass that plays an important role in the soil ecosystem where they have crucial role in nutrient cycling. It has been reported that field application of glyphosate increased microbial biomass carbon by $17 \%$ and microbial biomass nitrogen by $76 \%$ in nine soils at 14 days after treatment. The soil microbial biomass $\mathrm{C}$ increased significantly upto 30 days in chlorpyrifos as well as cartap hydrochloride treated soil, but thereafter decreased progressively with time. Soil nematodes, earthworms and protozoa are affected by field application rates of the fungicide fenpropimorph and other herbicides. Thus, there is need to assess the effect of indiscriminate use of pesticides on soil microorganisms, affecting microbial activity and soil fertility.
\end{abstract}

Keywords: Herbicides, Insecticides, Microbial biomass, Mycorrhiza, Soil enzymatic activity

\section{INTRODUCTION}

Pesticides are the important agrochemicals used in agricultural system for prevention of crops from pests. Pesticides are often applied several times during one crop season and a part always reaches the soil. The wide use of pesticides has created numerous problems, including the pollution of the environment. The influence of pesticides on soil microorganisms is dependent on physical, chemical and biochemical conditions, in addition to nature and concentration of the pesticides (Aurelia, 2009; Sethi et al., 2013). In many studies it was demonstrated that microorganisms are capable to grow in the presence of several commercial pesticides. Catabolism and detoxification metabolism occur when soil microorganism uses the pesticide as a carbon and energy source. Most pesticides work by poisoning pests. A systemic pesticide moves inside a plant following absorption by the plant. With insecticides and most fungicides, this movement is usually upward (through xylem) and outward (Shinde et al., 2015). Systemic insecticides, which poison pollen and nectar in the flower may kill bees and other needed pollinators. Subclasses of pesticides include herbicides, insecticides, fungicides, rodenticides, pediculicides and biocides (Stoytcheva, 2011). Pesticides would pollute air, soil and water resources, contaminate the food chain and disrupt ecosystem balance. For example, high concentrations of pesticides in soil may influence processes such as plant growth and the activity and diversity of biotic populations. Continuous use of pes- ticides may accumulate appreciable quantities of pesticides and their degradation products in the soil ecosystem (Kumar et al., 2012). Pesticides that disrupt the activities of soil microbes may affect the nutritional quality of soils, resulting in serious ecological consequences (Handa et al., 1999).

The application of pesticides starts from the pre-sowing stage of crop growth. The indiscriminate use of pesticides disturbs the soil environment by affecting flora and fauna including microflora of soil, and also the physico-chemical properties of the soil like $\mathrm{pH}$, salinity, alkalinity leading to infertility of soil (Sarnaik et al., 2006). When pesticides are applied, the possibilities exist that these chemicals may have certain effects on non-target organisms, including soil micro organisms. Pesticides in the soil affect the nontarget and beneficial micro-organisms (Bhuyan et al., 1992) and their activities which are essential for maintaining soil fertility (Schuster and Schroder, 1990). The microbial biomass plays an important role in the soil ecosystem where they fulfill a crucial role in nutrient cycling and decomposition (De-Lorenzo et al., 2001). Modern agriculture worldwide uses a variety of pesticides including insecticides, nematicides, herbicides and fungicides to optimize crop production. However, continuous application of pesticides may result in soil pollution threatening processes driven by soil micro organisms and thereby, affecting soil fertility (Lopez et al., 2002; Cycon et al., 2006).

With increased pesticides use, questions on potential effects regarding public health and the environment 
has developed. Many of the studies only examined initial effects of pesticides in laboratory microcosms, rather than in integrated system over long periods and at larger scales. Soil is not only a medium for agricultural production, but is often viewed as a filter and processor for xenobiotics; and how a soil is managed can determine its ability to function in this capacity (Locke and Zablotowicz, 2004).

Much of the research on herbicides effects on soil biota has been done overseas. It was reported that increase in reliance on herbicides in zero-till systems in Australia has no doubt had impacts on soil biota. The application of chlorosulfurone increased root disease by Rhizoctonia solani but had no effect on take -all levels (Rovira and McDonald, 1986). Glyphosate and chlorosulfurone have each been associated with increased levels of Pythium root rot in barley seedlings (Blowes, 1987), and take-all fungus (Mekwatanakarn and Sivasithamparam, 1987). If a fungicide improves crop growth though eliminating foliar or soil borne diseases, than increased organic matter in the system will generally boost microbial activity. Fungicides may however have direct effects on the non target organisms particularly these saprobic and symbiotic soilborne fungi. Benomyl for instance is particularly toxic to mycorrizal fungi (Smith et al., 2000) which could have implications for the nutritions of the plants. Foliar - applied sprays that miss the target, leaves and spray drift could also cause undesired/unintentional impacts on soil biota. Glyphosate has stimulated populations of fungi and actinomycetes with general increase in over all microbial activity even though bacterial populations were reduced (Araujo et al., 2003). Cypermethrin and monocrotophos had adverse effects on soil bacteria while fenvalerate had very low effect on the soil microbes (Rangaswamy and Venkateswarlu, 1992; Ajaz et al., 2005).

The toxicity level of a pesticide depends on the deadlines of the chemical, the dose, the length of exposure, and the route of entry or absorption by the body (Kumar, 2015). Pesticide degradation in soil genetically results in a reduction in toxicity, however some pesticides have breakdown products (metabolites) that are more toxic than the parent compound. Pesticides are classified according to their potential toxicity to humans and and other animals and organisms, as restricted use and general use (NRCS, 1998; Damalas and Eleftherohorinos, 2011).

Pesticides effects on soil microbial biomass: Measurement of total soil microbial biomass (typically measured as carbon or nitrogen in biomass) is an extremely useful tool for interpreting soil biological quality. Specific soil microflora constituents can be ascertained based on abundance of specific cellular components. Microbial biomass is a part of organic matter in soil that constitutes living microorganisms smaller than 5-10 cubic micrometers and it is the fraction of soil organic matter that is sensitive to management prac- tices and pollution (Powlson, 1994). Soil microbial biomass is an important attribute of soil quality as well as crop ecology (Doran and Parkin, 1994; Beelen and Doelman, 1997). Microbial biomass is a standardized component of ecotoxicity assessment in OECD guidelines for pesticides registration.

Glyphosate use with in North and South America has increased dramatically with use of transgenic herbicide -resistant crops, thus effects on soil ecological processes are of concern. Haney et al. (2000) observed no effect of glyphosate on soil microbial biomass 3 days after application. However, Haney et al. (2002), demonstrated that field application rates of the isopropylamine glyphosate salt increased microbial biomass carbon $(17 \%)$ and microbial biomass nitrogen $(76 \%)$ in nine soils at 14 days after treatment. Hart and Brookes (1996) showed that glyphosate increased microbial biomass carbon (16\%) 56 days after an autumn field application. In field trials, normal and tenfold field application rates of rimsulfuron had no effect on biomass carbon. However, under laboratory conditions, doses 10 and 100X field application rates elicited reduced soil biomass (Perucci and Scarponi, 1996).

Soil microbial biomass measurements has been reported to give an early indication of long-term changes in soil organic matter content, long before such changes could be measured by conventional techniques (Hart and Brookes, 1996). Microorganisms form a vital part of the soil food web, therefore microbial biomass is considered to be a measure of potential microbiological and ecosystem functioning (Rath et al., 1998). However for proper understanding of ecosystem functioning and determining soil disturbances because of various agricultural management practices, microbial activities must also be determined (Nannipieri et al., 2003) along with microbial activity in soil has been reported as a criteria for evaluating pesticide toxicity (Jones and Ananyeva, 2001).

Chemical pesticides had made a great contribution to the fight against pests and diseases. However, their widespread and long-term use resulted in insecticide resistance and biomagnifications of insecticides, which in turn resulted in restrictions on their export. Problems, like soil and water contamination and dramatic increase of the harmful residues in many primary and derived agricultural products arose, which endangered both the general environment and human health. Microbial and biochemical parameters of soil are choice indicators of soil quality evaluations (Winding et al., 2005) because of their early responses to soil disturbances than those of the physical and chemical parameters. The study was therefore initiated to evaluate the effect of pesticides and biopesticides on soil microbial biomass carbon in soil at controlled laboratory conditions. Piotrowska-Seget et al. (2008) performed a laboratory study to assess the impact of applying successive doses of oxytetracycline (bactericide) or Captan (fungicide) on microbial biomass and activity. 
They reported that both oxytetracycline and Captan significantly decreased the numbers of culturable bacteria, although total bacterial biomass was not affected. The study indicated that oxytetracycline or Captan application may negatively affect non-target soil microorganisms and their activities. The soil microbial biomass $\mathrm{C}$ increased significantly upto 30 days in chlorpyrifos as well as cartap hydrochloride treated soil, but thereafter decreased progressively with time (Kumar et al., 2012). Comparing the pesticides (Cypermethrin, Malathion, Victor, Monocil and Tafgor) and biopesticides Sethi and Gupta (2013) reported in Victor treated soil, a drastic decrease in microbial biomass $\mathrm{C}$ was observed as compared to others. However, $\mathrm{MBC}$ content increased with time in biopesticide treated soil.

Pesticides effects on soil fauna: Soil fauna (e.g. earthworms, nematodes, microarthropods, protozoans) are important in organic matter (OM) transformations and soil structure formation, and are useful bio-indicators to study Xenobiotic ecotoxicity in soil. Effects of longterm benomyl application in a tall grass prairie were assessed on nematode populations (Smith et al., 2000). Benomyl had no significant effect on herbivores , but significantly reduced certain fungal feeders (Tylenchidae) by $13 \%$ and predatory nematodes (Dorylamidae) by 33\%. Soil nematodes, earthworms and protozoa are affected by field application rates of the fungicide fenpropimorph and other herbicides. Application of fungicide, carbendazim resulted in reduction of various species of soil fungi extensively in first 20 days (Aggarwal et al., 2005). It was reported that Prosulfuron, an herbicide inhibited $\mathrm{N}_{2} \mathrm{O}$ and NO production by the bacteria (Kinney et al. 2005). They also reported that Mancozeb and chlorothalonil inhibited $\mathrm{N}_{2} \mathrm{O}$ and NO production. Gupta (1994) reported reductions of soil protozoa due to recommended rates of 2,4$\mathrm{D}$, simazine, diuron, monuron, cotoron. However, increase in protozoa attributed to stimulation of bacteria and fungal populations as herbicide is decomposed. Diazinon decreased protozoan populations (Ingham and Coleman, 1984). Dodd and Jeffries (1989) reported decrease in mycorrhizal fungi when the application of herbicides was done. Earthworms were also affected in gerenal by application of herbicides. Mele and Carter (1999) however reported no effect on earthworms in top $10 \mathrm{~cm}$ soil layer. Fraser et al. (1994) found that earthworms were extremely sensitive to organophosphate and carbamates and less sensitive to organochlorines. Copper oxychloride used as fungicide in orchards is found to be very toxic for earthworms (Lee, 1985). Pandey and Singh (2004) reported that application of chlorpyrifos reduced bacterial population while there was significant increase in fungal population.

Pesticides effects on Mycorrhiza: Symbiosis of mycorrhizal fungi with plants is another mutualistic plantmicrobial association. Mycorrhizal roots have an al- tered morphology that enhances nutrient and wateruptake. Fumigants used as nematicides and fungicides can profoundly influence mycorrhizal establishment. Mycorrhizal fungi can be relatively susceptible to certain fungicides - particularly when the fungicide is applied to the seed or into the soil; while other fungicides can stimulate mycorrhizal growth. Most foliar fungicide sprays (except those that are systemic - e.g. bayleton, benomyl, captan, etc), when applied properly and at recommended rates generally do not affect Mycorrhiza - as the Mycorrhiza in soil do not come in contact with the fungicide. For example, in potatoes, no effect has been observed on Mycorrhiza in programs that have included fungicides Maxim \& Amistar, Metham Sodium (100L/acre on loamy soil, 300L/ acre on sand). Bravo and Mancozeb (Manebe) - has shown variable results - usually compatible as a foliar - but poor as a seed treatment. Insecticides - Nemacur has no effect on Mycorrhiza, chlorpyrifos has no effect at low rate, but tends to suppress at high rate; whereas Phenylpyrazole inhibits Mycorrhiza (Ayman et al., 1996; Storer, 2012).

Pesticides effects on soil fertility: Some pesticides developed to boost crop yields could affect the soil fetility. In soil, the native and applied nutrients are transformed or mineralized for plant availability mediated through soil microbes. Common pesticides block the chemical signals that allow nitrogen-fixing bacteria to function. Over time, soils surrounding treated plants can become low in nitrogen compounds, so more fertilizer is needed to produce the same yield (Fox et al., 2007).

Sustainable agricultural practices often use crop rotation: growing a different crop in the same soil each year. Alternating crops, such as beans or clover- with crops like wheat, that don't fix nitrogen, enables soils to enhance nitrogen levels routinely. Leguminous plants contain root nodules that use soil bacteria to fix nitrogen, a process that converts atmospheric nitrogen into useful compounds like ammonia (Kumar, 2015).

Several common pesticides were tested on leguminous alfalfa plants, relying on the plants' nitrogen-fixing bacteria to provide the nutrients. The insecticides methyl parathion (not used in the UK, but widely used throughout the world, and registered in at least 38 countries) and DDT (which was banned by the World Health Organization for almost 30 years, before being reinstated in 2006 as an effective intervention against malaria) showed a decrease in crop yield of about 20 per cent. Treatment with pentachlorophenol, showed a decrease in crop yield of over 80 per cent (Fox et al., 2007).

The insecticides DDT, methyl parathion, and especially pentachlorophenol have been shown to interfere with legume-rhizobium chemical signaling. Reduction of this symbiotic chemical signaling results in reduced nitrogen fixation and thus reduces crop yields (Rockets, 2007). Root nodule formation in these plants 
Table 1. Effect of pesticides on enzyme activity in soil.

\begin{tabular}{|c|c|c|}
\hline Enzyme activity & Effect & References \\
\hline \multirow[t]{2}{*}{ Nitrogenase } & $\begin{array}{l}\text { It is observed that the decrease in total nitrogenase activity } \\
\text { (measured from pots sown with Pisum sativum plants) with } \\
\text { the application of herbicides. }\end{array}$ & Singh and Wright (1999) \\
\hline & $\begin{array}{l}\text { Repeated applications of pesticides significantly stimulated } \\
\text { rhizosphere-associated nitrogenase activity. }\end{array}$ & $\begin{array}{l}\text { Kanungo et al. (1995) Patnaik et al. } \\
(1995,1996) .\end{array}$ \\
\hline Dehydrogenase & $\begin{array}{l}\text { It is reported that the effect of organophosphate insecticide } \\
\text { (quinalphos) on dehydrogenase activity (DHA) in soil and } \\
\text { observed 30\% (p<0.05) inhibition in DHA after } 15 \text { days. }\end{array}$ & Mayanglambam et al. (2005) \\
\hline Urease & $\begin{array}{l}\text { Increase or decrease in urease activity following various } \\
\text { pesticide applications. }\end{array}$ & $\begin{array}{l}\text { Antonious (2003); Chen et al. (2001); } \\
\text { Ingram et al. (2005); Nowak et al. (2004) }\end{array}$ \\
\hline
\end{tabular}

saves the world economy $\$ 10$ billion in synthetic nitrogen fertilizer every year (Fox et al., 2007; Kumar, 2015).

Effect of pesticides on soil enzyme: Soil contains free enzymes, immobilized extracellular enzymes, and enzymes within microbial cells (Mayanglambam et al., 2005). They are indicator of biological equilibrium (Frankenberger and Tabatabai, 1991), fertility (Schuster and Schroeder, 1990; Nannipieri, 1994; Antonious, 2003), quality (Dick, 1994; Bucket and Dick, 1998), and changes in the biological status of soil due to pollution (Nannipieri et al., 1990; Nannipieri and Bollag, 1991; Schaffer, 1993; Trasar-Cepeda et al., 2000).

The role of soil enzymes and their activities are defined by their relationships with soil and other environmental factors (e.g., acid rain, heavy metals, pesticides, and other industrial chemicals) that affect their activities (Burns, 1982). Pesticides reaching the soil may disturb local metabolism or enzymatic activities (Topp et al., 1997; Engelen et al., 1998; Liu et al., 2008). Negative impact of pesticides on soil enzymes like hydrolases, oxidoreductases and dehydrogenase activities has been widely reported in the literature (Perucci and Scarponi, 1994; Ismail et al., 1998; Monkiedje and Spiteller, 2002; Menon et al., 2005). The impact of pesticide (insecticide, herbicide and fungicide) application on the health of paddy field soil showed a decrease in soil dehydrogenase activity with increased pesticide concentrations and toxicity increased in the order insecticide $>$ fungicide $>$ herbicide (Subhani et al., 2002).

Nitrogenase is the enzyme used by organisms to fix atmospheric nitrogen gas $\left(\mathrm{N}_{2}\right)$. Application of pesticides affects the efficiency and activity of nitrogenase enzyme. Singh and Wright (1999) observed a decrease in total nitrogenase activity (measured from pots sown with Pisum sativum plants) with the application of herbicides (Table 1). Adverse effects of pesticides have also been reported on nitrogenase activities of $\mathrm{N}_{2-}$ fixing bacteria, purple nonsulfur bacteria, methylotrophic bacteria, and cyanobacteria (Chalam et al., 1997; Martinez Toledo et al., 1998; Hammouda, 1999; Durska, 2004). In contrary, repeated applications of pesticides significantly stimulated rhizosphere-associated nitrogenase activity (Kanungo et al., 1995; Patnaik et al., 1995, 1996).

Dehydrogenases occur intracellularly in all living microbial cells and it is linked with microbial respiratory processes (Bolton et al., 1985). Dehydrogenase activity in soil is an indicator of overall microbial activity of soils. Mayanglambam et al. (2005) studied the effect of organophosphate insecticide (quinalphos) on dehydrogenase activity (DHA) in soil and observed $30 \%(\mathrm{p}<0.05)$ inhibition in DHA after 15 days. DHA was recovered after 90 days of treatment which may be due to adaptation of soil microbes to counter the effect of chemical stress in hostile conditions.

Hydrolases are of particular importance on account of their role in the soil nitrogen, phosphorus, carbon, and sulfur cycles (Megharaj et al., 1999). Urease is an enzyme that catalyzes the hydrolysis of urea into $\mathrm{CO}_{2}$ and $\mathrm{NH}_{3}$ and is a key component in the nitrogen cycle in soils. Urease activity is found in a large number of soil bacteria and fungi (Sarathchandra et al., 1984). Phosphatase is an exocellular enzyme produced by many soil microorganisms and is responsible for the hydrolysis of organic $\mathrm{P}$ compounds to inorganic $\mathrm{P}$ (Monkiedje et al., 2002). Several researchers have shown either unchanged, increase or decrease in urease activity following various pesticide applications (Antonious, 2003; Chen et al., 2001; Ingram et al., 2005; Nowak et al., 2004).

Effect of pesticides on carbon and nitrogen mineralization: Carbon mineralization is an important parameter for assessing side effects of pesticides (Sommerville, 1987; Alef, 1995). Haney and Senseman (2000) observed that herbicide treatement significantly stimulated $\mathrm{C}$ and $\mathrm{N}$ mineralization in soil. Chen et al. (2001) compared the efect of benomyl, captan and chlorothalonil on soil nitrogen dynamics in laboraory incubations with or without additions of organic materials. Both nitrogen mineralization and nitrification rates were influenced by all fungicides, with captan eliciting the greatest influence on minerilization rates. Captan increased soil $\mathrm{NH}_{4}-\mathrm{N}$, whereas benomyl or chlorothalonil had little impact. Martinez-Toledo et al. (1998) showed that captan $(2-10 \mathrm{~kg} / \mathrm{ha})$ inhibited nitrifying bacteria in four soils (50-90\%) during a 30 day study. Applying bensulfuron at normal field rates had no effect on nitrification, whereas cinosulfuron transiently inhibited nitrification after 1 week, but had 
no effect after 4 weeks. Nitrogen mineralization processes, such as ammonification and nitrification, are also affected by the application of pesticides, with the former being inhibited less because it is carried out by a vast diversity of microflora. Odokuma and Osuagwu (2004) have shown that the organochlorine pesticides Lindane and dieldrin were more toxic than the organophosphate pesticides pirimphos methyl and malathion to Nitrosomonas, Nitrobacter and Thiobacillus.

Pesticide degrading microbial populations: It is well documented that with certain pesticides, repeated applications can promote microbial populations capable of selectively degrading that pesticide. The capability of a soil for accelerated degradation might limit the use of that pesticide or related pesticides to control a particular pest. Bacterial isolates can degrade various organophosphorus pesticides (Kanekar et al., 2004). Pseudomonas spp.A1113 uses dimethoate and parathion as sole source of carbon and hence grows on the minimal medium and can be used for decontamination of pesticide polluted areas (Shinde et al., 2015).

\section{Conclusion}

Chemical pesticides had made a great contribution to the fight against pests and diseases. Soil contamination and dramatic increase of the harmful residues in many primary and derived agricultural products arose, which endangered both the general environment and human health. Microbial and biochemical parameters of soil are choice indicators of soil quality evaluations Pesticides in the soil affect the non-target and beneficial micro-organisms and their activities which are essential for maintaining soil fertility. Soil bacteria, fungi and almost all flora and fauna populations were reported to reduce and also soil microbial activity, biomass $\mathrm{C}$ and $\mathrm{N}$ mineralization got affected due to use of chemical pesticides. Judicious use of chemicals and use of bio-pesticides needs to be promoted to save soil health vis-à-vis human health.

\section{REFERENCES}

Aggarwal, A., Sharma, D., Prakash, V., Sharma, S. and Gupta, A. (2005). Effect of bavistin and dithane M-45 on the mycorrhizae and rhizosphere microbes of sunflower. Helia, 28(42): 75-88.

Ajaz, M., Jabeen, N., Akhtar, S. and Rasool, S.A. (2005). Chlorpyrifos resistant bacteria from Pakistani soils: isolation, identification, resistance profile and growth kinetics. Pak. J. Bot., 37 (2): 381-388.

Alef, K. (1995). Estimation of soils respiration. In: Methods in applied soil microbiology and biochemistry. Alef, K. and Nannipieri, P. (eds.) Academic Press, London, pp 215-216.

Antonious, G.F. (2003). Impact of soil management and two botanical insecticides on urease and invertase activity. $J$. Environ. Sci. Health B, 38: 479-488.

Araujo, A.S.F., Monterio, R.T.R. and Abarkeli, R.B. (2003). Effect of glyphosate on the microbial activity of two Brazilian soils. Chemosphere, 52:799-804.

Aurelia, O. (2009) Study of the effect of some pesticides on soil microorganisms. Analele Universităţii din Oradea, Fascicula: Protecţia Mediului Vol. XIV: 763-765.

Ayman M.O. Mirghani and Elsiddig A.E. Elsheikh (1996). Interaction of VA mycorrhizal fungi and root-knot nematode on tomato plants: Effects of nemacur, phosphorus and infection time. Elbuhuth Scientific J., 5: 88107.

Beelen, P.V. and Doelman, P. (1997). Significance and application of microbial toxicity tests in assessing ecotoxicological risks of contaminants in soil and sediment. Chemosphere, 34: 455-499.

Bhuyan, S., Sahu, S.K., Adhya, T.K. and Sethunathan, N. (1992). Accelerated aerobic degradation of $\gamma$ hexachlorocyclohexane in suspensions of flooded and non-flooded soils pretreated with hexachlorocyclohexane. Biol. Fertil. Soils, 12: 279-284.

Blowes, W.M. (1987). Effect of ryegrass root residues, knock-down herbicides, and fungicides on the emergence of barley in sandy soils. Australian Journal of Experimental Agriculture, 27: 785-790.

Bolton, H., Elliot, L.F., Papendick, R.I. and Bezdicek, D.F. (1985). Soil microbial biomass and selected soil enzymes activities: Effect of fertilization and cropping practices. Soil Biol. Biochem., 17: 297-302.

Bucket, J.Z. and Dick, R.P. (1998). Microbial and soil parameters in relation to $\mathrm{N}$ mineralization in soils of diverse genesis under differing management systems. Biol. Fertil. Soils, 27: 430-438.

Burns, R.G. (1982). Enzyme activity in soil: Location and a possible role in microbial ecology. Soil Biol. Biochem., 14: 423-427.

Chalam, A.V., Sasikala, C., Ramana, C.V., Uma, N.R., and Rao, P. R. (1997). Effect of pesticides on the diazotrophic growth and nitrogenase activity of purple nonsulfur bacteria. Bull. Environ. Contam. Toxicol., 58: 463-468.

Chen, S.K., Edwards, C.A. and Subler, S. (2001). Effect of fungicides benomyl, captan and chlorothalonil on soil microbial activity and nitrogen dynamics in laboratory incubations. Soil Biol. Biochem., 33: 1971-1980.

Cycon, M., Piotrowska-Seget, Z., Kaczynska, A. and Kozdro J. (2006). Microbiological characteristics of a sandy loam soil exposed to tebuconazole and 1-cyhalothrin under laboratory conditions. Ecotoxicology, 15:639-646.

Damalas, C.A. and Eleftherohorinos, I.G. (2011). Pesticide exposure, safety issues, and risk assessment indicators. Int. J. Environ. Res. Pub. Health 8(5): 1402-1419.

De-Lorenzo, M.E., Scott, G.I. and Ross, P.E. (2001). Toxicity of pesticides to aquatic microorganisms: a review. Environ. Toxicol. Chem., 20: 84-98.

Dick, R.P. (1994). Soil enzyme activities as indicators of soil quality. In: Defining soil quality for sustainable environment. Special Pub. 35. JW, Doran DC, Coleman DF, Bezdicek and Stewart BA (eds.) Soil Science Society of America, Inc., Madison, WI. Pp. 107-124.

Dodd, J.C. and Jeffries, P. (1989). Effects of herbicides on three vesicular-arbuscular fungi associated with winter wheat (Triticum aestivum L.). Biol. Fertil. Soils, 7:113-119.

Doran, J.W. and Parkin, T.B. (1994). Defining and assessing soil quality. In: J.W. Doran, D.C. Coleman, D.F. Bezdicek, B.A. Stewart (eds), Defining soil quality for sustainable environment, Special Pub.35. Soil Science Society of America, Madison, WI, pp 3-21.

Durska, G. (2004). Fungicide effect on nitrogenase activity in methylotrophic bacteria. Pol. J. Microbiol., 
53:155-158.

Engelen, B., Meinken, K., Von Wintzingerode, F., Heuer, H., Malkomes, H.P. and Backhaus, H. (1998). Monitoring impacts of a pesticide treatment on bacterial soil communities by metabolic and genetic fingerprinting in addition to conventional testing procedures. Appl. Environ. Microbiol., 64: 2814-2821.

Fox, J.E., Gulledge, J., Engelhaupt, E., Burrow, M.E. and McLachlan, J.A. (2007). Pesticides reduce symbiotic efficiency of nitrogen-fixing rhizobia and host plants. Proceedings of the National Academy of Sciences of the USA 104(24): 10282-10287.

Frankenberger, W.T. Jr. and Tabatabai, M.A. (1991). 2 Glutaminase activity of soils. Soil Biol. Biochem., 23: 869-874.

Fraser, P.M., Haynes, R.J. and Williams, P.H. (1994). Effects of pasture improvement and intensive cultivation on microbial biomass, enzyme activities, and composition and size of earthworm population. Biol. Fertil. Soils, 17:185-190.

Gupta, V.V.S.R. (1994). The impact of soil and crop management practices on the dynamics of soil microfauna and mesofauna. In "Soil Biota: Management in Sustainable Farming Systems". Eds. C.E. Pankhurst, B.M. Doube, V.V.S.R. Gupta and P.R. Grace. pp. 107-124. CSIRO Australia, Melbourne.

Hammouda, O. (1999). Response of the paddy field cyanobacterium Anabaena doliolum to carbofuron. Ecotoxicol. Environ. Saf. 44: 215-219.

Handa, S.K., Agnihotri, N.P. and Kulshreshtha, G. (1999). Pesticide residues; significance, management and analysis. Research Periodicals and Book Publishing House, Texas.

Haney, R.L. and Senseman, S.A. (2000). Effect of glyphosate on soil microbial activity and biomass. Weed Sci., 48: 89-93.

Haney, R.L., Senseman, S.A. and Hons, F.M. (2002). Effect of Roundup Ultra on microbial activity and biomass from selected soils. J. Environ Qual., 31:730-735.

Haney, R.L., Senseman, S.A., Hons, F.M. and Zuberer, D.A. (2000). Effect of glyphosate on soil microbial activity and biomass. Weed Sci., 48: 89-93.

Hart, M.R., and Brookes, P.C. (1996). Soil microbial biomass and mineralization of soil organic matter after 19 years of cumulative field applications of pesticides. Soil Biol. Biochem, 28: 1641-1649.

Ingham, E.R. and Coleman, D.C. (1984). Effects of streptomycin, cycloheximide, fungizone, Captan, Carbofuron, Cygon and PCNB on soil microorganisms. Microbial Ecology, 10: 345-358.

Ingram, C.W., Coyne, M.S. and Williams, D.W. (2005). Effects of commercial diazinon and imidacloprid on microbial urease activity in soil. J. Environ. Qual., 34: 1573-1580.

Ismail, B. S., Yapp, K. F. and Omar, O. (1998). Effects of metsulfuron-methyl on amylase, urease, and protease activities in two soils. Aust. J. Soil Res. 36: 449-456.

Jones, W.J. and Ananyeva, N.D. (2001). Correlations between pesticide transformation rate and microbial respiration activity in soil of different ecosystems. Biol. Fertil. Soils, 33: 477-483.

Kanekar, P.P., Bhadbhade, B., Deshpande, N.M. and Sarnai, S.S. (2004). Biodegradation of organophosphorus pesticides. Proc. Indian Natl. Sci. Acad., Part B70(1): 57-70.
Kanungo, P.K., Adhya, T.K. and Rao, V.R. (1995). Influence of repeated applications of carbofuran on nitrogenase activity and nitrogen-fixing bacteria associated with rhizospere of tropical rice. Chemosphere, 31:3249-3257.

Kinney, C.A., Mandernack, K.W. and Mosier, A.R. (2005). Laboratory investigations into the effects of the pesticides mancozeb, chlorothalonil and prosulfuron on nitrous oxide and nitric oxide production in fertilized soil. Soil Biol. Biochem., 37: 837-850.

Kumar, V. (2015). A review on efficacy of biopesticides to control the agricultural insect's pest. International Journal of Agricultural Science Research, 4(9): 168-179.

Kumar, A., Nayak, A.K., Shukla, A.K., Panda, B.B., Raja, R., Shahid, M., Tripathi, R., Mohanty, S. and Rath, P.C. (2012). Microbial biomass and carbon mineralization in agricultural soils as affected by pesticide addition. Bull. Environ. Contam. Toxicol. 88: 538-542.

Lee, K.E. (1985). Earthworms: their ecology and relationships to soils and land use. Academic Press, New York.

Liu, J., Xie, J., Chu, Y., Sun, C., Chen, C., and Wang, Q. (2008). Combined effect of cypermethrin and copper on catalase activity in soil. J. Soils Sed., 8, 327-332.

Locke, M.A. and Zablotowicz, R.M. (2004). Pesticides in Soil - Benefits and limitations to soil health. In: Managing Soil Quality: Challenges in Modern Agriculture (P. Schjonning, S. Elmholt, B.T. Christensen, Eds.), CABI Publishing, pp. 239-260.

Lopez, L., Pozo, C., Gomez, M.A., Calvo, C., and Gonzales Lopez, J. (2002). Studies on the effects of the insecticide aldrin on aquatic microbial populations. Int. Biodeter. Biodegr., 50: 83-87.

Mayanglambam, T., Vig, K. and Singh, D.K. (2005). Quinalphos persistence and leaching under field conditions and effects of residues on dehydrogenase and alkaline phosphomonoesterases activities in soil. Bull. Environ. Contam. Toxicol., 75: 1067-1076.

Martinez-Toledo, M.V., Salermon, V., Rodelas, B., Pozo, C. and Gonzalez-Lopez, J. (1998). Effects of the fungicide captan on some functional groups of soil microflora. Appl. Soil Ecol., 7: 245-255.

Megharaj, M., Boul, H.L. and Thiele, J.H. (1999). Effects of DDT and its metabolites on soil algae and enzymatic activity. Biol. Fertil. Soils., 29: 130-134.

Mekwatanakarn, P. and Sivasithamparam, K. (1987). Effect of certain herbicides on saprophytic survival and biological suppression of the take-all fungus. New Phytology, 106: 153-159.

Mele, P.M. and Carter, M.R. (1999). Impact of crop management factors in conservation tillage farming on earthworm density, age structure and species abundance in south-eastern Australia. Soil and Tillage Research, 50: $1-10$.

Menon, P., Gopal, M., and Parsad, R. (2005). Effects of chlorpyrifos and quinalphos on dehydrogenase activities and reduction of $\mathrm{Fe}^{3}$ in the soils of two semi-arid fields of tropical India. Agric. Ecosyst. Environ., 108: 73-83.

Monkiedje, A., and Spiteller, M. (2002). Effects of the phenylamide fungicides, mefenoxam and metalaxyl, on the biological properties of sandy loam and sandy clay soils. Biol. Fertil. Soils, 35, 393-398.

Monkiedje, A., Ilori, M.O. and Spiteller, M. (2002). Soil quality changes resulting from the application of the fungicides mefenoxam and metalaxyl to a sandy loam soil. Soil Biol. Biochem., 34: 1939-1948.

Nannipieri, P. (1994). The potential use of soil enzymes as 
indicators of productivity, sustainability and pollution. In: Soil Biota: Management in Sustainable Farming Systems (C. . Pankhurst, B.M. Doube, V.V.S.R. Gupta, and P.R. Grace, Eds.), pp. 238-244. CSIRO, East Melbourne.

Nannipieri, P. and Bollag, J.M. (1991). Use of enzymes to detoxify pesticide-contaminated soils and waters. J. Environ. Qual., 20: 510-517.

Nannipieri, P., Gregos, S. and Ceccanti, B. (1990). Ecological significance of the biological activity in soil. In: Soil Biochemistry. Vol. 6. Smith, J.L. and Paul, E.A.(eds.). Marcel Dekker, Inc., New York, USA, pp. 293-354.

Nannipieri, P., Ascher, J., Ceccherini, M.T., Landi, L., Pietramellara, G. and Renella, G. (2003). Microbial diversity and soil functions. Eur. J. Soil Sci., 54: 655-670.

Nowak, A., Nowak, J., Klodka, D., Pryzbulewska, K., Telesinski, A. and Szopa, E. (2004). Changes in the microflora and biological activity of the soil during the degradation of isoproturon. J. Plant Dis. Protec., 19: $1003-1016$.

NRCS (1998). Soil Quality Concerns: Pesticides. Soil Quality Information Sheet, National Soil Survey Center, Soil Quality Institute, NRCS, USDA, National Soil Tilth Laboratory, Agricultural Research Service, USDA, http://www.nrcs.usda.gov/Internet/ FSE_DOCUMENTS/ nrcs142p2_052821.pdf (Retrieved on 12/12/2015)

Odokuma, L.O. and Osuagwu, C. (2004). Tolerance of chemolithotrophic bacteria to organochlorine, organophosphate and carbamate pesticides. J. Agr. Environ. Eng. Technol., 1(1):7-15.

Pandey, S. and Singh, D.K. (2004). Total bacterial and fungal population after chlorpyrifos and quinalphos treatments in groundnut (Arachis hypogaea L.) soils. Chemosphere, 55: 283-290.

Patnaik, G.K., Kanungo, P.K., Moorthy, B.T.S., Mahana, P.K., Adhya, T.K. and Rao, V.R. (1995). Effect of herbicides on nitrogen-fixation $\left(\mathrm{C}_{2} \mathrm{H}_{2}\right.$ reduction) associated with rice rhizosphere. Chemosphere, 30: 339-343.

Patnaik, G.K., Kanungo, P.K., Adhya, T.K. and Rao, V.R. (1996). Effect of repeated applications of gammahexachlorocyclohexane (gamma-HCH) on nitrogenase activity and nitrogen-fixing bacteria associated with rhizosphere of tropical rice. Microbiol. Res., 151:375-378.

Perucci, P. and Scarponi, L. (1994). Effects of the herbicide imazethapyr on soil microbial biomass and various soil enzyme activities. Biol. Fertil. Soils, 17: 237-240.

Perucci, P. and Scarponi, L. (1996). Side effects of rimsulfuron on the microbial biomass of a clay-loam soil. J. Env. Qual., 25: 610-613.

Piotrowska-Seget, Z., Engel, R., Nowak, E. and Kozdroj, J. (2008). Successive soil treatment with Captan or oxytetracycline affects non-target microorganisms. World J. Microbiol. Biotechnol., 24: 2843-2848.

Powlson, D.S. (1994). The soil microbial biomass: before, beyond and back. In: Dighton, J., Giller, K.E., Ritz, K. (eds) Beyond the biomass. Wiley, Chichester.

Rangaswamy, V. and Venkateswarlu, K. (1992). Degradation of selected insecticides, monochrotophos, quinalphos, cypermethrin and fenvalerate, by bacteria isolated from soil. Bull. Env. Contam. Toxic., 49 (6): 797-804.

Rath, A.K., Ramakrishnan, B., Kumaraswamy, S., Bharati, K., Singla, P. and Sethunathan, N. (1998) Effect of pesticides on microbial biomass of flooded soil. Chemosphere, 37: 661-671.
Rockets, Rusty (2007). Down of the farm ? Yields, Nutrients and Soil Quality. Take action! How to eliminate Pesticides use. National Audubon Society, pp 1-3.

Rovira, A.D. and McDonald, H. (1986). Effects of herbicide chlorsulfuron on Rhizoctonia bare patch and take-all of barley and wheat. Plant Disease, 70: 879-882.

Sarathchandra, S.U., Perrott, K.W. and Upsdell, M.P. (1984). Microbiological and biochemical characteristics of a range of New Zealand soils under established pasture. Soil Biol. Biochem., 16: 177-183.

Sarnaik, S.S., Kanekar, P.P., Raut, V.M., Taware, S.P., Chavan, K.S. and Bhadbhade, B.J. (2006). Effect of application of different pesticides to soybean on the soil microflora. J. Env. Biol., 27(2): 423- 426.

Schaffer, A. (1993). Pesticide effects on enzyme activities in the soil ecosystems. In: Soil Biochemistry (J.M. Bollag and Y.G. Stotzk, Eds.), pp. 273-340. Marcel Dekker, New York.

Schuster, E. and Schroder, D. (1990). Side-effects of sequentially and simultaneously applied pesticides on nontarget soil microorganisms: Laboratory experiments. Soil Biol. Biochem., 22: 375-383.

Sethi, S. and Gupta, S. (2013). Impact of Pesticides and Biopesticides on Soil Microbial Biomass Carbon. Universal J. Env. Res. Tech., 3(2): 326-330.

Sethi, S., Mathur, N. and Bhatnagar, P. (2013) Growth response of microbial population exposed to synthetic pyrethroids. Int. J. Env. Sci. 4(1): 42-53.

Shinde, S.R., Bhailume, M.V., Patil, N.B., Patil, N.N. and Hamde, V.S. (2015). Screening, characterization and identification of soil isolates for degradation of organophosphorus group of pesticides (Dimethoate and Parathion). Int.J.Curr.Microbiol.App.Sci., 2: 240-244.

Singh, G., and Wright, D. (1999). Effect of herbicides on nodulation, symbiotic nitrogen fixation, growth and yield of pea (Pisum sativum). J. Agric. Sci. 133: 21-30.

Smith, M.D., Hartnett, D.C. and Rice, C.W. (2000). Effects of long-term fungicide applications on microbial properties in tallgrass prairie soil. Soil Biol. Biochem., 32: 935-946.

Sommerville, L. (1987). Perspective on side effect testing. In: Sommerville, L., Greaves, M.P. (eds) Pesticide effects in soil microflora. Taylor and Francis, London.

Storer, Paul (2012). The effect of fungicide and insecticides on Mycorrhiza. Western Mineral Fertilizers, Australia.

Stoytcheva, M. (2011). Pesticides in the modern world-risks and benefits. Role of pesticides in human life in the modern age. Intech open access publisher.

Subhani, A., Min, L., Chango-Yong, H., Zheng-miao, X. (2002). Alteration of certain soil microbiological and biochemical indices of a paddy soil under anthropogenic stress. J. Zhejiang Univ. Sci., 3(4):467-474.

Topp, E., Vallaeys, T. and Soulas, G. (1997). Pesticides: Microbial degradation and effects on microorganisms. In: Modern Soil Microbiology (J.D. van Elsas, J.T. Trevors and E.M.H. Wellington, Eds.), pp. 547-575. Marcel Dekker, New York.

Trasar-Cepeda, C., Leiros, M.C., Seoane, S. and Gil-Sotres, F. (2000). Limitation of soil enzymes as indicators of soil pollution. Soil Biol. Biochem., 32: 1867-1875.

Winding, A., Kerstin, H.R. and Rutgers, M. (2005). The use of microorganisms in ecological soil classification and assessment concepts. Ecological and Environmental Safety, 62(2): 230-248. 